\title{
Application of Internet and Big Data Technology to Give Full Play to the Function of Procuratorial Civil Public Interest Litigation in China
}

\author{
Qian Zhang* \\ Shandong University of Political Science and Law, Shandong, China \\ *Corresponding Author.
}

\begin{abstract}
:
The procuratorial civil public interest litigation system is a kind of legal system, which will realize certain legal functions. As an important way for procuratorial organs to exercise their functions and powers, procuratorial civil public interest litigation system in China has many functions: on the one hand, it has the core function of protecting social public interests; on the other hand, it has the main function of enforcing laws, forming public policies and promoting social governance; and it has the guiding function of providing reference for similar reforms. How to fully give play to the function of procuratorial civil public interest litigation, the big data is an important means. Procuratorial organs should make full use of the information of data platform, and enhance the joint efforts of public welfare protection, and set up the thinking of handling cases with information and improve application ability, so as to plug in "wisdom wings" for the procuratorial civil public interest litigation.
\end{abstract}

Keywords: Procuratorate Organ, Civil Public Interest Litigation, Big Data, Application, Fuction

\section{COMPARATIVE ANALYSIS ABOUT THE FUNCTIONS OF PROCURATORIAL CIVIL PUBLIC INTEREST LITIGATION SYSTEM}

There are many valuable opinions about the functions of the procuratorial civil public interest litigation system in the theoretical circles at home and abroad. For example, some scholars think that we should understand the function of public interest litigation from the perspective of constitution. It is the way to realize legal supervision for procuratorial organs. Some scholars believe that the civil procuratorial public interest litigation has the function of safeguarding the entity and procedural justice, guarding the social public interest and national 
interest, and has the value of restriction and governance [1]. Other experts think that the procuratorial organ, as the representative of the state and social public interest, brings civil public interest litigation as the last relief means to safeguard social public interest [2].

In foreign countries, the public interest litigation initiated by procuratorial organs has the function and value of general public interest litigation. Some experts believe that public interest litigation, as a political practice, aims to add an access of marginalized groups such as women and the poor to the legal system through judicial means, so that they can understand their rights [3]. Some scholars believe that public interest litigation can build social peace mechanism, reduce the possibility of future violent conflict map, reduce social differentiation and establish a stronger rule of law [4]. Other scholars have analyzed the functions of the public interest litigation in policy making, political mobilization, government supervision and law enforcement. They believe that the public interest litigation is conducive to the supply of public goods and social change, and prompt the government to take timely action against public policy or public interest issues. It is the cheapest opportunity to enter political life. The above view about the functions of the procuratorial civil public interest litigation is different understandings from different angles. Some of them locate its functions from the height of the constitution, some sort out the functions of the procuratorial civil public interest litigation from the perspective of the public interest representative theory, and others complete its functions from the perspective of social equity and public policy reform. In conclusion, there are no fundamental differences in these different understandings. The author believes that the functions of the procuratorial civil public interest litigation system are diversified, but there are differences between the primary and secondary functions. From the logical angle, the functions of the procuratorial civil public interest litigation should be divided into core function, secondary function and reference function.

\section{THE BASIC FUNCTIONS OF THE PROCURATORIAL CIVIL PUBLIC INTEREST LITIGATION SYSTEM IN CHINA}

The procuratorial civil public interest litigation is the way to perform the function of legal supervision, and its core function is to protect the public interest. The reason why there is a special civil public interest litigation system outside the ordinary civil litigation is that the purpose of public interest litigation and private interest litigation is completely different. The purpose of traditional civil litigation is to relieve private rights, which belongs to subjective litigation. The purpose of civil public interest litigation is to protect public interest. The procuratorial civil public interest litigation is a special kind of civil public interest litigation, which is reflected in the difference of the subject of litigation. It is a legal system which is designed to protect social public interest. This system is based on the legal supervision and 
public interest representative status of the procuratorial organ. Its main function is to maintain the social public interest and objective legal order. It is a typical objective litigation. This legal system makes up for the absence of the procuratorial organs to file civil public interest litigation, and has become an important way to perform their legal supervision function.

The secondary functions of procuratorial civil public interest litigation include the enforcement of laws, the formation of public policies and the promotion of social governance. First of all, procuratorial civil public interest litigation has the function of law enforcement. Since the middle of the 20th century, "social problems" such as consumption and environmental protection emerged, which affected individual rights and public interests. The traditional private interest relief lack the motivation to solve these social problems, and the administrative organs also lack the willingness to protect the public interest. Therefore, many countries begin to reform the litigation rules from the perspective of safeguarding public interest, and make up for the deficiency of administrative law enforcement through judicial means. Civil litigation played the role of implementing social policies and presented a trend of socialization. Traditional civil public interest litigation had the characteristics of "mixed blood" of civil litigation and administrative law enforcement [5]. For example, in the field of environment, the enforcement of environmental law should be mainly completed by administrative organs. However, due to "institutional capture", political pressure, lack of resources and other reasons, administrative agencies are unwilling or unable to fully implement environmental laws. But environmental public interest litigation can overcome the disadvantages of inadequate law enforcement by administrative organs, which is an important method to supplement administrative law enforcement. It can strengthen the protection of environmental public interests, solve the group social disputes caused by environmental damage, improve the enthusiasm of administrative organs to exercise their functions, and better implement environmental protection laws, which has become a key means to protect public interest [6]. The environmental public interest litigation has become the main means to promote the implementation of environmental law [7]. Therefore, civil public interest litigation has become a special judicial mechanism to make up for the lack of public interest protection in administrative law enforcement [5]. From the current situation in China, with the rapid development of more than 40 years, a mass of environmental and food safety problems have emerged. In particular, the environmental situation is particularly severe. The old environmental problems have not been solved, and new environmental problems have emerged again. Environmental pollution is still serious. The foundation of environmental governance is very weak, especially some local governments and environmental supervision departments pursue economic growth unilaterally, which leads to insufficient environmental supervision. Environmental protection is a systematic project, which needs multi-party cooperation. It can not only rely on administrative law enforcement, but also need the supplementary law 
enforcement role of justice.

As China's judicial and legal supervision organ, the constitutional orientation of procuratorate is legal supervision. The law endows procuratorial organ with the power to file civil public interest litigation. On the one hand, it can alleviate the problem that social organizations are not enthusiastic about civil public interest litigation. On the other hand, it can play a complementary role in law enforcement. The civil public interest litigation from the procuratorial organ is a new way to play the function of legal supervision through litigation.

Secondly, the procuratorial civil public interest litigation system also has the function of forming public policy and promoting social governance. The formation of public policy and the promotion of social governance belong to the social function of procuratorial civil public interest litigation. The social function emphasizes the actual influence on society and the effect of social governance. The traditional civil litigation focuses on solving the right disputes between individuals. The consequence of litigation will not affect the third party, and the litigation function will not be expanded. The effect of civil judgment is strictly limited between the parties, so there will be no expansion in res judicata. However, public interest litigation is based on the maintenance of public interest. The consequences of litigation involve an unspecified majority of people. The function of litigation is greatly expanded, which can have a broad and direct impact on the society. The formation of public policy and the promotion of social governance is the basic form of the expansion of public interest litigation function. From the practice of public interest litigation all over the world, it is committed to those who bear the loss in the distribution of social resources, and seek new ways to protect the rights of vulnerable groups in law and reality through litigation [8]. Therefore, the public interest litigation transforms public policy into legal issues, and the judicial organs make the judgment results that meet the needs of the public through due process. The judgment content can generally become the recognized social value, and cause some pressure on the actual political organs, which can be used as the reference or basis for policy-making. Taking the environmental public interest litigation as an example, in the civil public interest litigation of Zhenjiang ecological environment public welfare protection association v. Jiangsu Youli optical glasses company, through judicial suggestions, the industry misevaluation on the attributes of solid waste has been changed. The difficult problem of solid waste pollution control has been solved, and a public policy beneficial to the maintenance of social public interest has been formed. As the representative of social public interests and legal supervision organs, the procuratorate has the authority to file civil public interest litigation in the fields of ecological environment and resource protection, food and drug safety, etc. Although it belongs to the supplementary right of action, it is the last line of defense to safeguard the public interest. With the exertion of legal supervision function, there will be certain political synergy and 
resultant force of public interest protection. Through the formation of public policy, procuratorial civil public interest litigation can solve the governance problems in the public fields such as ecological environment, and improve the level of legalization and modernization of national governance.

The reference function of the procuratorial civil public interest litigation system reflects the practical value of the system itself in correctly handling the dialectical relationship between reform and the rule of law, and has typical guidance or reference value for similar reforms. Reform and law are like two wings of a bird. They are interdependent symbiotic relationship. Reform and rule of law have unity, also have differences in the characteristics of thinking, behavior, function and evaluation, but they are basically the same. To correctly understand and deal with the dialectical relationship between reform and the rule of law, we need to improve the corresponding legislative methods [9]. The dialectical relationship between the reform and the rule of law reflects that the reform should be carried out under the guidance of the rule of law, and the rule of law is constantly improved in the process of reform. As an important part of this round of judicial system reform, the procuratorial public interest litigation system reflects the positive interaction between the two. From the top-level design of the public interest litigation system initiated by the procuratorial organs in the Fourth Plenary Session of the 18th CPC Central Committee, to the pilot exploration authorized by the Standing Committee of the National People's Congress, and then to the revision of the civil procedure law in 2017, the reform achievement were officially fixed in the form of law. The reform process of procuratorial public interest litigation system is carried out orderly under the premise of legislative empowerment. After the pilot project is completed, the system is formally established through legislation. From the operation practice of procuratorial public interest litigation system, the effectiveness of the system is very significant. It not only effectively protects the public interest, but also explores the way to solve the worldwide problem of "tragedy of the commons". It has become an important institutional innovation to promote national governance and social governance through the rule of law. The procuratorial public interest litigation is the most important content on the reform of public interest litigation system in recent years, which improves the level of legalization of public interest maintenance. Therefore the legal system of public interest protection is constantly improved in the reform of public interest litigation system. From this point, it can be said that the establishment of the procuratorial public interest litigation system better interprets the dialectical relationship between reform and the rule of law, and realizes the mutual promotion and win-win situation between them, which has certain reference significance for similar reform in the future.

\section{HOW TO GIVE FULL PLAY TO THE FUNCTION OF PROCURATORIAL CIVIL PUBLIC INTEREST LITIGATION IN CHINA---FROM THE PERSPECTIVE OF BIG}




\section{DATA}

The modern working mode is facing challenges from all aspects of the information society, and the procuratorial organs are in a wave of new technology revolution represented by the Internet. At the same time, the problems of lack of theoretical consensus, lack of clues and difficulty in obtaining evidence seriously restricts the function of the public prosecution litigation. At present, most of the public interest litigation cases use manual investigation method for routine information collection, and the clue collection is time-consuming and labor-consuming. The collected data need to be analyzed and processed through the prosecutor's own experience. The prosecutor is not an administrative manager or an administrative law enforcer, and has no relevant knowledge background on the administrative law enforcement details of the case, It is difficult to analyze and judge illegal data clues directly. The bigdata, cloud computing and other technologies can help the procuratorial organ to broaden the way of case source discovery, establish case related information database, assist the investigators to analyze and make decisions on cases, give full play to their functions such as case push and risk assessment, liberate the prosecutors from the tedious writing and consulting work, effectively improve the efficiency of case handling, and solve the problem of more cases and less people; At the same time, we can use the auxiliary case handling system to assist prosecutors in conviction and sentencing, and provide more intelligent tools for case handling. Therefore, in order to better perform the function of legal supervision, procuratorial organ must actively embrace the big data. The information technology represented by big data is the innovation and revolution of procuratorial work nowadays. In the information age, the big data is the foundation and the key. Especially, the public interest litigation cases involve a lot of fields, and the procuratorial organs lack relevant data such as oceans, rivers, mountains and so on. If big data is the means, then the procuratorial civil public interest litigation is the carrier, and its development is the purpose. Therefore, the procuratorial organ can build a data command center to access the data of multiple functional departments. Through the construction of electronic data cloud platform, the procuratorial organ can make the original data of many units form a data pool, and mine the maximum value of data, so that the data can better support the development of the procuratorial civil public interest litigation (Fig.1).

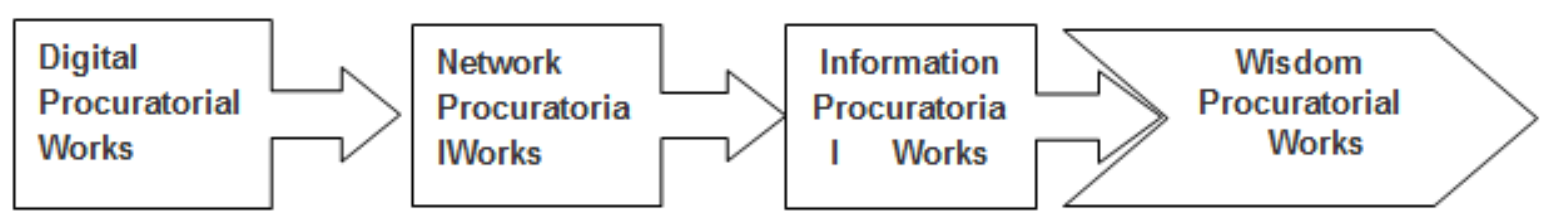

Fig.1 The Process of Information Construction of Procuratorial organ 
How to build a big data platform? Firstly, it needs the leadership of the procuratorial organ and the joint participation of multiple functional departments. In the information age, no department or individual can survive alone. In the process of public interest litigation, the goal of procuratorial organ is to protect public interests. Therefore, the procuratorial organ should start from the cases, actively dock with the relevant administrative organs, access to the data network, so as to realize the information sharing and interconnection of case resources. Secondly, procuratorial organ should set up the thinking of handling cases with information. Judicial case handling is facing the challenges of the information age. The procuratorial organ should take the thinking of handling cases with information as the guide, greatly improve the application ability of the electronic data, and provide data support for the public interest litigation investigators to find clues through the use of data resources.

Thirdly, procuratorial organ should explore the establishment of a data sharing platform with administrative law enforcement, which has the following functions. The platform is based on big data and cloud computing to expand the field of analysis, research and judgment. At the same time, with the help of artificial intelligence technology, it can automatically classify and correlate cases, discover the information of supervision points and source of cases, and realize information-based case management and intelligent auxiliary case handling. Also, it can also provide the management function of research and judgment rules and case completion index, summarize the prosecutor's case handling experience, and refine it into a description language that can be recognized by computer. With the help of machine learning technology, it can actively recommend the source of cases and early warning, so as to improve the level of intelligent management. It can also provide prosecutors with a flexible multi angle case source search push function, through the red, yellow and blue light grading warning, high warning level priority push. In particular, it can analyze and judge a single case source, recommend the power list of relevant administrative law enforcement units and similar case sources, and facilitate the prosecutors to handle cases. The above-mentioned technological breakthroughs effectively guarantee the cutting-edge and application of the platform construction. 


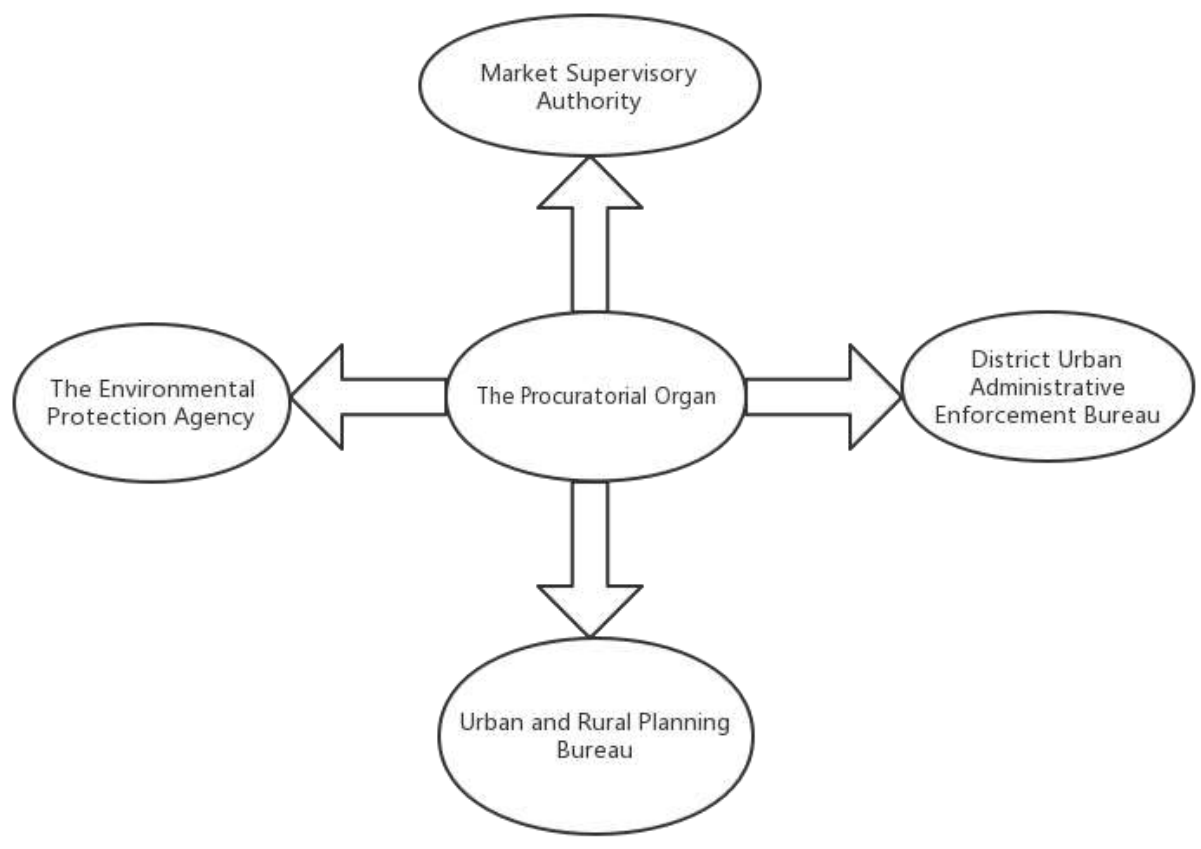

Fig.2 The Procuratorial Organ and some Administrative Organizations

Fourth, the procuratorial organ should strengthen the construction of informatization team. Procuratorial team is always at the forefront in the process of information construction. Under the background of big data, procuratorial organs will face endless new cases. They need to constantly learn information knowledge, improve application and identification ability, standardize case handling activities through the improvement of information ability, and boost the full play of procuratorial public interest litigation function (Fig.2).

\section{SUMMARY}

The life of law lies in the realization. The law itself can not influence the deep-rooted social situation widely. It needs a certain intermediary mechanism to change the law on paper into the law in life. As a kind of legal system, the procuratorial civil public interest litigation system should be carefully analyzed for what function it has played in society and whether it has realized the function of law. The paper makes a preliminary study on the functions of the procuratorial civil public interest litigation system, then analyzes the practice of the system in China, and concludes that its functions are diversified. From the logical point of view, the functions of the procuratorial civil public interest litigation should be divided into core function, secondary function and reference function. Therefore, a correct analysis of the 
function about the procuratorial civil public interest litigation is essential for the improvement and development of the system in the future. But how to give full play to the function of the procuratorial civil litigation is a major issue in front of us. Therefore, the author believes that the procuratorial organ need to build a big data platform. Through extensive collection of clues, we can actively act to make every potential public welfare damage case clue present, let the procuratorial organs make full use of the information of data platform, enhance the timeliness of case discovery and enhance the joint efforts of public welfare protection. At the same time the procuratorial organ should set up the thinking of handling cases with information and improve application ability, so as to plug in "wisdom wings" for the procuratorial civil public interest litigation.

\section{REFERENCES}

[1] Xiao Jianguo. The value of civil procuratorial supervision, procuratorial daily, May 3, 2019.

[2] Chen Ruihua. On the legal functions of procuratorial organ, Tribune of Political Science and Law (2018) No.1.

[3] Helen Hershkoff. Public Law Litigation: Lessons and Questions, Hum Rights Rev (2009) No.10.

[4] Andrea Theresa Bibee. Litigation For Peace: The Impact of Public Interest Litigation in Divided Societies, the degree of Master of the Graduate School of the University of Oregon (2013).

[5] Gong Gu. Reflectionon the nature of environmental civil public interest litigation, Chinese Journal of Law (2019) No.3.

[6] Chen Liang. Research on environmental public interest litigation, Law Press 2015.

[7] Lv Zhong Mei. Environmental public interest litigation: a comparison between China and the United States, Law Press 2008.

[8] Xu Hui. The road to social justice-Theoretical Research on public interest litigation, Law Press2008.

[9] Yuan Shuhong. Correctly understand and handle the relationship between reform and the rule of law under the new situation, Journal of the National Academy of administration (2015) NO.5. 